\title{
Mobbing i arbeidslivet og senere helseplager
}

\begin{abstract}
BAKGRUNN Tverrsnittsstudier viser at eksponering for mobbing $\mathrm{i}$ arbeidslivet er positivt relatert til selvopplevde helseplager. Studiene gir imidlertid ikke grunnlag for å konkludere om hvorvidt mobbing fører til økte helseplager eller om helseplager øker risikoen for å bli mobbet. For å gi bedre indikasjoner på årsak-virkning-forhold oppsummeres derfor kunnskap fra prospektive studier på sammenhenger mellom mobbing i arbeidslivet og helseutfall.
\end{abstract}

MATERIALE OG METODE Vi har gjort en systematisk litteraturgjennomgang av originalartikler fra sentrale litteraturdatabaser om longitudinelle sammenhenger mellom mobbing i arbeidslivet og helse. Gjennomsnittsammenhenger mellom mobbing og helseutfall er beregnet ved bruk av metaanalyse.

RESULTATER Et konsistent funn på tvers av de gjennomgåtte studier er at eksponering for mobbing er signifikant positivt relatert til psykiske (OR $=1,68$; $95 \% \mathrm{KI} 1,35-2,09$ ) og somatiske plager ( $\mathrm{OR}=1,77 ; 95 \% \mathrm{KI} 1,41-2,22$ ) over tid. Psykiske plager er også forbundet med senere eksponering for mobbing $(\mathrm{OR}=1,74 ; 95 \% \mathrm{KI} 1,44-2,12)$.

FORTOLKNING Mobbing er positivt relatert til psykiske og somatiske helseplager. Assosiasjonen mellom psykiske plager og senere mobbing indikerer en selvforsterkende prosess mellom mobbing og psykisk helse. De gjennomgåtte studier er av relativt god metodisk kvalitet. Med utgangspunkt i eksisterende kunnskapsgrunnlag er det imidlertid ikke grunnlag for konklusjoner om entydige årsak-virkning-forhold mellom mobbing og helse.

Mobbing i arbeidslivet er gjennom de siste 20 år blitt aktualisert gjennom medieoppslag og forskning. Med begrepet «mobbing» menes en situasjon der en person gjentatte ganger over tid utsettes for negative handlinger fra en eller flere andre $i$ arbeidsmiljøet og hvor den som er utsatt, ikke klarer å forsvare seg mot disse handlingene (1). Mobbing dreier seg altså om vedvarende trakassering, ikke om enkeltstående konfliktepisoder. Ulikheter i styrkeforhold mellom mobber og den eksponerte kan ha utgangspunkt $\mathrm{i}$ både formelle posisjoner og uformelle psykologisk maktforhold.

Mobbing kan ha en lang rekke ytringsformer, men i forskningslitteraturen er det vanlig å skille mellom direkte og indirekte mobbing (1). Førstnevnte viser til åpent krenkende handlinger som utskjelling, upassende morsomheter på offerets bekostning og urettmessig kritikk av vedkommendes arbeidsinnsats. Indirekte mobbing viser til handlinger som sosial ekskludering og baksnakking. Det er også vanlig å skille mellom personrelatert og arbeidsrelatert mobbing. Personrelatert mobbing manifesteres gjennom handlinger som krenker en arbeidstakers personlige integritet. Eksempler på arbeidsrelatert mobbing er å bli satt til arbeid under sitt kompetansenivå og tilbakeholding av informasjon som er nødvendig for å utføre arbeidsoppgaver.

Fra et juridisk ståsted vil handlinger som kan regnes som legitime innenfor lovverkets rammer og påregnelige innenfor et gitt arbeidsforhold ikke regnes som mobbing, selv om de subjektivt kan oppleves som krenkende av en arbeidstaker (2). I de fleste studier tar man imidlertid et subjektivt utgangspunkt - ved at de er basert på arbeidstakerens opplevelser (3).

I forskningslitteraturen er mobbing blitt kartlagt ved bruk av to metoder. Med eksponeringsmetoden undersøkes respondentenes eksponering for konkrete mobbehandlinger. Selvvurderingsmetoden innebærer at man spør respondentene om de synes de er blitt utsatt for mobbing eller ikke, gjerne etter å ha presentert en definisjon av mobbebegrepet. I tråd med disse metodene viser landsrepresentative tall at omtrent $14 \%$ av norske arbeidstakere har vært utsatt for systematiske mobbehandlinger. 4,6\% har følt seg mobbet i løpet av de siste seks måneder (4).

I og med at mobbing $\mathrm{i}$ arbeidslivet er en langvarig og systematisk form for trakassering innenfor en viktig livsarena, er det rimelig å anta at det har helsemessige konsekvenser. Dette blir underbygd av resultater fra tverrsnittsstudier, som viser at eksponering for mobbing er positivt korrelert med både fysiske og psykiske helseplager. I en metaanalyse av tverrsnittsstudier ble det funnet en gjennomsnittlig korrelasjon på 0,34 mellom mobbing og psykiske plager og en korrelasjon på 0,28 mellom mobbing og somatiske plager (3). Disse korrelasjonene viser at høy eksponering for mobbing gjennomgående henger sammen med høy grad av helseplager. informasjon om den kausale retningen på de
Tverrsnittsstudier gir imidlertid ingen

\author{
Morten Birkeland Nielsen \\ morten.nielsen@stami.no \\ Statens arbeidsmiljøinstitutt \\ og \\ Institutt for samfunnspsykologi \\ Universitetet i Bergen

\section{Nils Magerøy} \\ Yrkesmedisinsk avdeling \\ Haukeland universitetssykehus \\ Johannes Gjerstad \\ Statens arbeidsmiljøinstitutt \\ og \\ Institutt for biovitenskap \\ Universitetet i Oslo

\section{Ståle Einarsen} \\ Institutt for samfunnspsykologi \\ Universitetet i Bergen
}

Podkast på www.tidsskriftet.no

Engelsk oversettelse på www.tidsskriftet.no

> Se lederartikkel side 1212

\section{HOVEDBUDSKAP}

Mobbing er et utbredt arbeidsmiljøproblem og rammer mellom $5 \%$ og $14 \%$ av norske arbeidstakere

Eksponering for mobbing i arbeidslivet er forbundet med senere psykiske og somatiske helseplager

Eksisterende helseplager er også forbundet med økt risiko for å bli utsatt for mobbing

Det mangler prospektive studier av mekanismer som forklarer relasjoner mellom mobbing og helseplager 
Tabell 1 Studier av sammenhenger mellom mobbing og helserelaterte faktorer

\begin{tabular}{|c|c|c|c|c|c|c|}
\hline Forfatter, år (referanse) & Land & $\begin{array}{c}\text { Antall } \\
\text { deltakere }\end{array}$ & $\begin{array}{l}\text { Tidsinter- } \\
\text { vall (md.) }\end{array}$ & Utvalg & $\begin{array}{l}\text { Sannsynlig- } \\
\text { hetsutvalg }\end{array}$ & Helsemål \\
\hline Brousse, 2008 (5) & Frankrike & 48 & 12 & Pasienter (behandlingsstudie) & Nei & Mental helse \\
\hline Eriksen, 2006 (6) & Norge & 4076 & 15 & Sykepleiere & $\mathrm{Ja}$ & Mental helse \\
\hline Figueiredo-Ferraz, 2013 (7) & Spania & 372 & 12 & Helsepersonell & Nei & Mental helse \\
\hline Finne, 2011 (8) & Norge & 1971 & 24 & Arbeidstakere generelt & Nei & Mental helse \\
\hline Hansen, 2013 (9) & Danmark & 1671 & 24 & Arbeidstakere generelt & Nei & Søvnproblemer \\
\hline Hoobler et al., 2010 (10) & USA & 1418 & 12 & Arbeidstakere generelt & $\mathrm{Ja}$ & Mental og somatisk helse \\
\hline Høgh, 2005 (11) & Danmark & 4647 & 60 & Arbeidstakere generelt & $\mathrm{Ja}$ & Mental helse \\
\hline Høgh, 2011 (12) & Danmark & 2154 & 12 & Helsearbeidere & $\mathrm{Ja}$ & Mental og somatisk helse \\
\hline Johannessen, 2013 (13) & Norge & 6745 & 36 & Arbeidstakere generelt & $\mathrm{Ja}$ & Mental helse \\
\hline Kiwimäki, 2003 (14) & Finland & 5431 & 24 & Sykehusansatte & Ja & $\begin{array}{l}\text { Kardiovaskulær sykdom } \\
\text { og mental helse }\end{array}$ \\
\hline Kiwimäki, 2004 (15) & Finland & 4791 & 24 & Sykehusansatte & $\mathrm{Ja}$ & Fibromyalgi \\
\hline Kääriä, 2012 (16) & Finland & 5277 & $60-84$ & Offentlig ansatte & Ja & Kroniske nakkesmerter \\
\hline Lahelma, 2012 (17) & Finland & 6830 & $60-84$ & Offentlig ansatte & $\mathrm{Ja}$ & Mental helse \\
\hline Lallukka, 2011 (18) & Finland & 7332 & $60-84$ & Offentlig ansatte & $\mathrm{Ja}$ & Søvnproblemer \\
\hline Lallukka, 2012 (19) & Finland & 6606 & $36-60$ & Offentlig ansatte & Ja & Bruk av psykofarmaka \\
\hline Nielsen, 2012 (20) & Norge & 1775 & 24 & Arbeidstakere generelt & $\mathrm{Ja}$ & Mental helse \\
\hline Nielsen, 2012 (21) & Norge & 741 & 6 & Offshoreansatte & $\mathrm{Ja}$ & Mental helse \\
\hline Reknes, 2013 (22) & Norge & 1582 & 12 & Sykepleiere & Nei & Mental helse \\
\hline Rugulies, 2012 (23) & Danmark & 5701 & 24 & Ansatte i eldreomsorgen & $\mathrm{Ja}$ & Mental helse \\
\hline Stoetzer, 2009 (24) & Sverige & 4040 & 36 & Arbeidstakere generelt & $\mathrm{Ja}$ & Mental helse \\
\hline Tepper, 2000 (25) & USA & 362 & 6 & Arbeidstakere generelt & Ja & Mental helse \\
\hline
\end{tabular}

Tabell 2 Metaanalyse av sammenhenger mellom mobbing, psykiske plager og somatiske plager ${ }^{1}$

\begin{tabular}{|c|c|c|c|c|c|c|c|c|}
\hline \multirow[b]{2}{*}{ Sammenheng } & \multirow[b]{2}{*}{ Antall studier } & \multirow[b]{2}{*}{ Antall } & \multirow[b]{2}{*}{ OR } & \multicolumn{2}{|c|}{$95 \% \mathrm{Kl}$} & \multirow[b]{2}{*}{$\begin{array}{l}\text { Heterogenitet } \\
\text { mellom studiene (Q) }\end{array}$} & \multirow[b]{2}{*}{$\begin{array}{l}\text { Heterogenitet } \\
\text { i prosent }\left(\left.\right|^{2}\right)\end{array}$} & \multirow[b]{2}{*}{ Fail-safe N } \\
\hline & & & & Lav & $\mathrm{Høy}$ & & & \\
\hline Mobbing - psykiske plager & 14 & 47473 & 1,68 & 1,35 & 2,09 & $184,41^{1}$ & 92,95 & 628 \\
\hline Psykiske plager - mobbing & 7 & 18300 & 1,74 & 1,44 & 2,12 & $30,36^{1}$ & 80,23 & 237 \\
\hline Mobbing - somatiske plager & 5 & 19071 & 1,77 & 1,41 & 2,22 & $10,02^{1}$ & 60,06 & 88 \\
\hline
\end{tabular}

${ }^{1} p<0,01$

observerte sammenhengene og forteller derfor ikke om mobbing fører til økte helseproblemer eller om det er slik at personer med allerede eksisterende helseplager er mer utsatt for å bli mobbet. Det kan for eksempel tenkes at personer med psykiske plager både har lettere for å oppleve negative hendelser som mobbing, samtidig som de også kan oppføre seg på en måte som utløser aggresjon hos andre.
Sammenliknet med tverrsnittsstudier har prospektive forskningsdesigner den fordelen at de gir informasjon om retningen på sammenhenger over tid. De vil derfor gi bedre indikasjoner på hvordan eksponering for mobbing henger sammen med helseplager. Hensikten med denne artikkelen er å oppsummere resultater fra forskningslitteraturen om prospektive sammenhenger mellom mobbing og helseplager.

\section{Materiale og metode}

Gjennomgangen er basert på originalartikler i forfatternes personlige litteraturarkiv. Arkivet ble opprettet i 1989 og inkluderte per 1.12. 2013 om lag 750 forskningsartikler om arbeidslivsrelatert mobbing. Arkivet oppdateres ukentlig og er basert på søk med søkeordene «mobbing», «bullying», «victimization», «harassment», kombinert med «workplace» og/eller «work», i litteratur- 


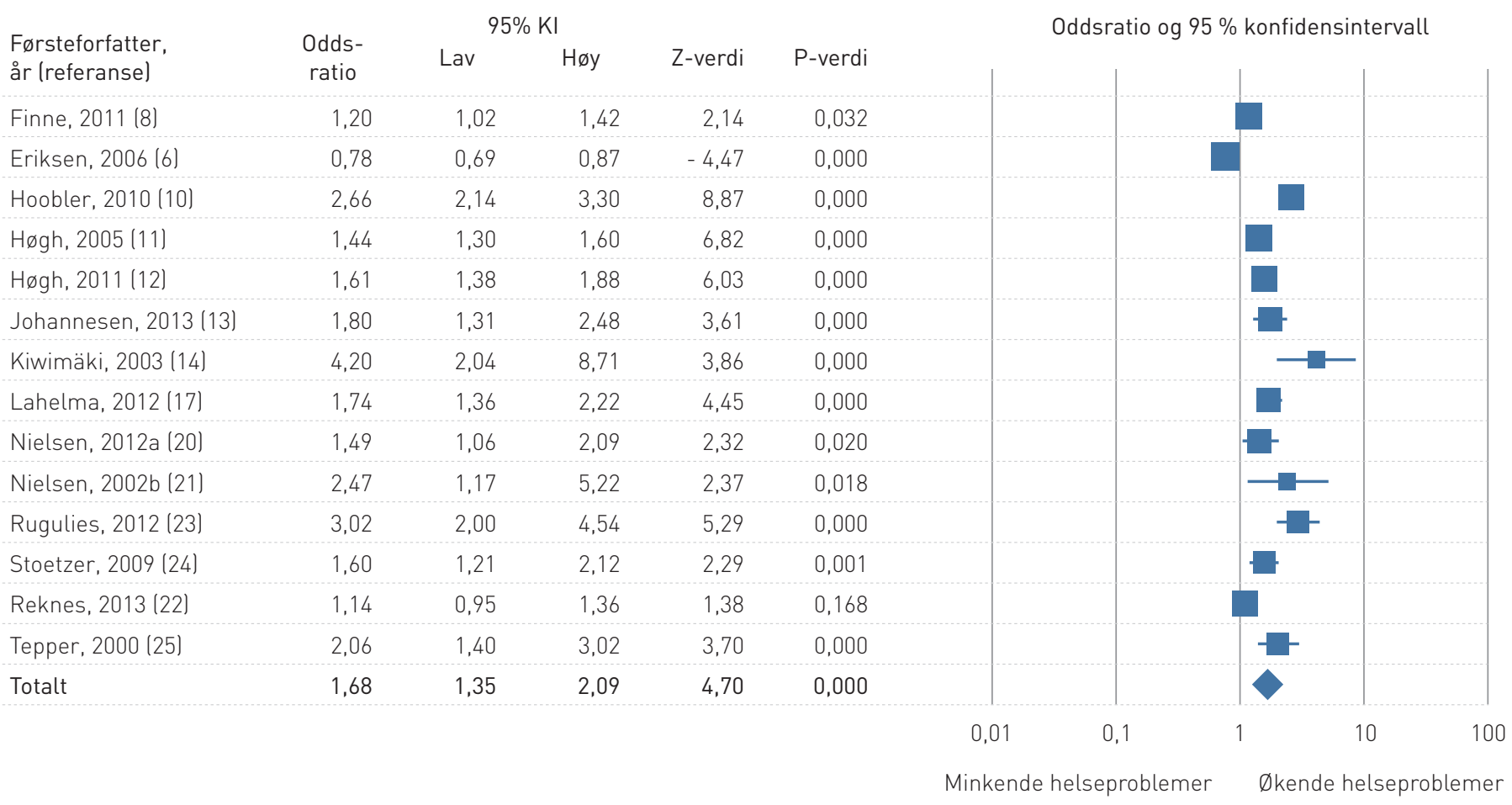

Figur 1 Balansediagram (forest plot) for studier av sammenhengen mellom eksponering for mobbing og senere psykiske plager

databasene PubMed, Web of Science (ISI), PsychInfo og Google Scholar. Det er ikke blitt satt historiske tidsbegrensninger på søkene. Den systematiske søkerutinen sannsynliggjør at arkivet omfatter samtlige publiserte studier om mobbing i arbeidslivet.

Til denne litteraturgjennomgangen ble det inkludert studier der prospektive sammenhenger mellom arbeidsrelatert mobbing og helseplager beskrives. Tverrsnittsstudier og prospektive studier som ikke omhandlet de relevante sammenhenger ble ekskludert. Gjennomgangen er begrenset til publiserte artikler i skandinaviske og internasjonale vitenskapelige tidsskrifter. Gjennomlesing og koding av studiene ble utført av førsteforfatter. Til sammen 21 studier svarte til inklusjonskriteriene (tab 1) (5-25).

17 studier hadde nordisk opprinnelse. Overvekten av nordiske studier er i tråd med tidligere litteraturgjennomganger $(3,26)$ og gjenspeiler det faktum at forskning på mobbing har sitt tyngdepunkt i Nord-Europa. I 16 studier undersøkte man om det var sammenhenger mellom mobbing og mental helse. Andre utfallsmål var somatiske plager, søvnproblemer og bruk av psykofar- maka. Tidsintervall mellom undersøkelsespunktene varierte fra seks måneder til 84 måneder (median $24 \mathrm{md}$.).

Gjennomsnittlig utvalgsstørrelse i de inkluderte studiene var 3503 (spredning 48-7 332). Hovedvekten av studiene var basert på generelle utvalg av arbeidstakere eller undersøkelser blant helsepersonell. Ut fra kriterier for sannsynlighetsutvelgelse, dvs. at alle i en gitt populasjon har lik sannsynlighet for deltakelse (27), var det i 16 av 21 studier anvendt sannsynlighetsutvalg. I flertallet av studiene var det benyttet selvvurderingsmetoden for å kartlegge mob-

\begin{tabular}{l|ccccc}
$\begin{array}{l}\text { Førsteforfatter, } \\
\text { år (referanse) }\end{array}$ & $\begin{array}{c}\text { Odds- } \\
\text { ratio }\end{array}$ & Lav & Høy & Z-verdi & P-verdi \\
\hline Finne, 2011 (8) & 2,30 & 1,43 & 3,70 & 3,44 & 0,001 \\
\hline Høgh, 2005 (11) & 1,39 & 1,21 & 1,49 & 5,45 & 0,000 \\
\hline Høgh, 2011 (12) & 1,29 & 1,11 & 1,50 & 3,25 & 0,001 \\
\hline Kiwimäki, 2003 (14) & 2,46 & 1,69 & 3,58 & 4,72 & 0,000 \\
\hline Nielsen, 2012 (20) & 2,27 & 1,74 & 2,95 & 6,11 & 0,000 \\
\hline Nielsen, 2002 (21) & 2,51 & 1,39 & 4,53 & 3,06 & 0,002 \\
\hline Reknes, 2013 (22) & 1,52 & 1,27 & 1,83 & 4,53 & 0,000 \\
\hline Totalt & 1,74 & 1,44 & 2,12 & 8,58 & 0,000
\end{tabular}

Oddsratio og $95 \%$ konfidensintervall

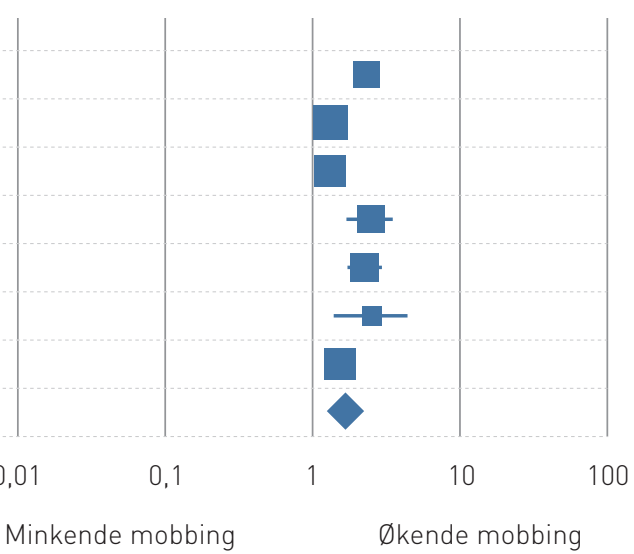

Figur 2 Balansediagram (forest plot) for studier av sammenhengen mellom psykiske plager og senere eksponering for mobbing 


\begin{tabular}{l|ccccc}
$\begin{array}{l}\text { Førsteforfatter, } \\
\text { år (referanse) }\end{array}$ & $\begin{array}{c}\text { Odds- } \\
\text { ratio }\end{array}$ & Lav & Høy & Z-verdi & P-verdi \\
\hline Hoobler, 2010 (10) & 1,80 & 1,46 & 2,22 & 5,46 & 0,000 \\
\hline Høgh, 2011 (12) & 1,44 & 1,23 & 1,68 & 4,64 & 0,000 \\
\hline Kiwimäki, 2003 (14) & 2,30 & 1,18 & 4,50 & 2,43 & 0,015 \\
\hline Kiwimäki, 2004(15) & 4,18 & 1,93 & 9,06 & 3,62 & 0,000 \\
\hline Kääriä, 2013(16) & 1,61 & 1,14 & 2,28 & 2,70 & 0,007 \\
\hline Totalt & 1,77 & 1,41 & 2,22 & 4,92 & 0,000
\end{tabular}

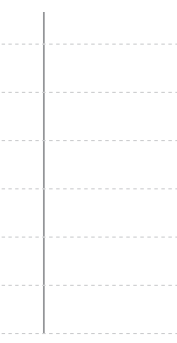

0,01

0,1
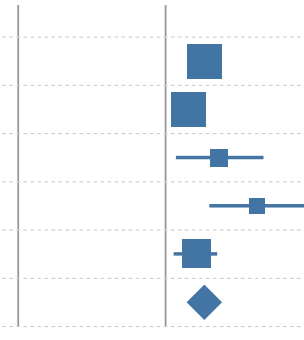

Minkende helseproblemer

100

$\emptyset$ kende helseproblemer

bing. Samtlige studier var basert på respondentenes selvrapporterte helseplager.

Gjennomsnittlig effektstørrelse på sammenhenger mellom mobbing og helse, heterogenitet (Q) mellom studiene og heterogenitet i prosent $\left(\mathrm{I}^{2}\right)$ samt risiko for publikasjonsskjevheter (Fail Safe N) ble beregnet ved hjelp av metaanalyse vektet for utvalgsstørrelse i programvaren Comprehensive Meta-Analysis versjon 2 (28). En signifikant Q-verdi indikerer at studiene er heterogene. Da de inkluderte studier på forhånd antas å være heterogene i utvalgssammensetning og bruk av måleinstrumenter, er metaanalysen basert på en slumpeffektmodell (random effects model) (28). Fail Safe $\mathrm{N}$ er et estimat på hvor mange upubliserte studier med ikkesignifikante resultater som vil være nødvendig for å øke p-verdien for resultatene fra metaanalysen til $>0,05$. Sammenliknet med en tidligere metaanalyse av sammenhenger mellom mobbing og helseplager (3) omfatter den foreliggende gjennomgangen et større antall studier og flere helseutfall.

\section{Resultater}

En oversikt over inkluderte studier er gjengitt i tabell 1 (5-25). Kunnskapsgrunnlaget for sammenhenger mellom mobbing og utfallene søvnproblemer og bruk av psykofarmaka er for begrenset til at man kan trekke konklusjoner, de er derfor ikke behandlet videre i resultatpresentasjonen.

Med ett unntak (6) ble det i samtlige studier påvist signifikante positive sammenhenger over tid mellom eksponering for mobbing ved første måletidspunkt og psykiske plager (angst og depresjon) ved oppfølging. 13 av 16 sammenhenger var justert for grad av stabilitet i psykiske plager hos respondentene mellom måletidspunktene. Dette indikerer dermed at mobbing er relatert til nye tilfeller av psykiske plager over tid.

Sammenhengen påvises både $\mathrm{i}$ generelle og mer yrkesspesifikke populasjoner. For eksempel viste en kohortstudie med 6745 norske arbeidstakere at mobbing predikerte senere psykiske plager $(\mathrm{OR}=1,80 ; 95 \% \mathrm{KI}$ $=1,31-2,48$ ) etter kontroll for eksisterende plager (13). I en finsk studie av sykehusansatte ble det funnet at mobbing var signifikant relatert til nye tilfeller av depresjon $(\mathrm{OR}=4,2 ; 95 \% \mathrm{KI}=2,0-8,6)$ to år senere (14). Av studiene på mobbing og psykiske plager kunne 14, med til sammen 47473 respondenter, inkluderes $\mathrm{i}$ en metaanalyse (tab 2, fig 1). Vektet for utvalgsstørrelse ga studiene en signifikant gjennomsnittlig oddsratio på $1,68(95 \% \mathrm{KI}=1,35-2,09)$. Sammenhengen er robust, da analyse av publikasjonsskjevheter viser at 628 studier med nullsammenhenger er nødvendig for få estimatet ikke-signifikant (Fail Safe N = 628).

I sju studier ble det rapportert sammenhenger mellom psykiske plager ved første måletidspunkt og mobbing ved oppfølging. Seks av studiene viste signifikante assosiasjoner over tid. For eksempel fant Finne og medarbeidere (8), etter å ha kontrollert for stabilitet i mobbing over tid, at angst og depresjon ved første måletidspunkt predikerte mobbing ved oppfølgingstidspunktet $(\mathrm{OR}=2,3 ; 95 \% \mathrm{KI}=1,43-3,69)$. Tilsvarende sammenheng er også rapportert i en landsrepresentativ undersøkelse av norske arbeidstakere (20), i en studie av norske sykepleiere (22) samt i en studie av finske sykehusansatte (14). Ved bruk av metaanalyse (tab 2, fig 2) gir disse sju studiene $(\mathrm{N}=18300)$ en oddsratio på $1,74(95 \% \mathrm{KI}$ 1,44-2,12; Fail Safe $\mathrm{N}=237$ ) for den longitudinelle sammenhengen mellom psykiske plager og senere eksponering for mobbing.

Når det gjelder somatiske plager, viser studiene i gjennomgangen signifikante relasjoner over tid mellom mobbing og generelle fysiske plager $(10,12)$, fibromyalgi (15) og kroniske nakkesmerter (16). Oppsummert ved metaanalyse ( $\operatorname{tab} 2$, fig 3 ) gir studiene en signifikant gjennomsnittlig oddsratio mellom eksponering for mobbing og senere somatiske plager på 1,77 (95\% KI $=1,41-2,22$; Fail Safe N = 94).

Sammenhenger mellom somatiske plager og senere eksponering for mobbing er kun blitt undersøkt $\mathrm{i}$ to studier. Resultatene fra disse er motstridende. I en studie med 2154 danske helsearbeidere ble det funnet en svak, men signifikant, korrelasjon $(r=0,07)$ mellom generelle fysiske plager og senere mobbing (12). I en finsk studie fant Kiwimäki og medarbeidere (14) at kardiovaskulær sykdom ikke predikerte senere eksponering for mobbing $(\mathrm{OR}=1,31 ; 95 \% \mathrm{KI}=0,88-1,94)$.

\section{Diskusjon}

Den foreliggende gjennomgang og metaanalyse viser at mobbing er signifikant positivt forbundet med senere psykiske og somatiske helseplager, samtidig som psykiske plager også er signifikant assosiert med senere eksponering for mobbing. Analyser av publikasjonsskjevheter indikerer at sammenhengene er robuste.

Én forklaring på hvordan eksponering for mobbing er relatert til økte mentale helseplager er at mobbing virker gjennom kognitive faktorer, slik som attribusjoner og fortolkninger. Dette innebærer at effekten av mobbing på helsen er betinget av hvordan den som er utsatt opplever, vurderer og forstår eksponeringen. Denne forklaringen understøttes av en prospektiv studie hvor det ble funnet at sammenhengen mellom mobbing og senere psykiske plager var assosiert med den subjektive opplevelsen av å være mobbet og ikke utelukkende ved at man er utsatt for mobbende handlinger (20).

Samtidig finnes det tverrsnittsstudier som antyder at kognitive faktorer har begrenset betydning for helseplager ved høyintens eksponering for mobbehandlinger $(29,30)$, noe som dermed indikerer at mobbingens alvorlighetsgrad likevel er den viktigste påvirkningsfaktoren for helseplager. 
Forskning omkring rettferdighet på arbeidsplassen viser at sammenhenger mellom det man finner urettferdig og psykisk helse fordrer at man opplever både urettferdig behandling og prosedyreurettferdighet $\mathrm{i}$ form av mangelfull adekvat inngripen fra arbeidsgiver (31). En alternativ forklaring er derfor at sammenhengen mellom mobbing og senere psykiske plager skyldes en kombinasjon av eksponering for mobbing og utilstrekkelig håndtering av konfliktsituasjonen på ledelsesnivå.

Resultatene tyder på at mobbing også kan manifesteres i senere somatiske plager. Det bør påpekes at en viktig mangel ved eksisterende litteratur er at det foreligger få studier der man har undersøkt hvorvidt somatiske plager predikerer senere eksponering for mobbing. En annen svakhet er det ikke finnes prospektive studier som viser hvordan eksponering for mobbing kan føre til somatiske plager. Med utgangspunkt i forskning som viser sammenhenger mellom depresjon og somatiske lidelser (32), kan en teoretisk forklaring imidlertid være at mobbing er indirekte relatert til somatiske plager gjennom psykisk helse.

Et viktig funn i gjennomgangen er den positive sammenhengen mellom psykiske plager og senere eksponering for mobbing. Resultatene gir imidlertid ikke noen pekepinn om hvorvidt personer med psykiske plager har en reelt forhøyet risiko for mobbing eller om det derimot er slik at psykiske plager gjør at man lettere føler at man blir mobbet. Denne gjensidige relasjonen mellom mobbing og mental helse kan indikere at mobbing og helseplager utgjør en selvforsterkende prosess, en ond sirkel (14).

\section{Metodisk kvalitet}

Majoriteten av studiene i gjennomgangen er basert på store sannsynlighetsutvalg fra generelle yrkespopulasjoner eller spesifikke sektorer som helsearbeidere og ansatte i petroleumsindustrien. At sammenhengene mellom mobbing og helseplager er konsistente på tvers av yrkesgrupper, tyder på at funnene er generaliserbare. Signifikante relasjoner til helse over både kortere $(6 \mathrm{md}$.) og lengre (5-7 år) tidsperioder indikerer at mulige helseplager inntreffer tidlig og er langvarige.

$\mathrm{Vi}$ vet derimot ikke hvordan disse sammenhengene utvikles over tid. Med ett unntak (12) er eksisterende studier basert på kun to måletidspunkter. For å undersøke dynamikken mellom mobbing og helseplager er det behov for studier med minimum tre måletidspunkter. Det mangler også longitudinell forskning på modererende og medierende faktorer som kan forklare når og hvordan mobbing er relatert til helseplager. Dette bør følges opp i videre forskning.
En annen svakhet ved de foreliggende studiene er at de er basert på selvrapporterte data for både mobbing og utfall. Det er dermed rimelig å anta at subjektive individfaktorer som personlighetstrekk og emosjonelle tilstander kan påvirke resultatene. En utfordring for fremtidig forskning blir derfor å innhente objektive data $\mathrm{i}$ form av registerdata eller kliniske vurderinger.

Selv om prospektive studiedesigner har den fordel at de indikerer retningen på en sammenheng over tid, gir de likevel ikke grunnlag for å konkludere om faktiske årsaksforhold. I tillegg vil slike designer ikke kunne utelukke påvirkning fra tredjevariabler, slik som premorbid personlighet og tidligere negative livshendelser, deriblant mobbing i barndommen. Med utgangspunkt i det eksisterende kunnskapsgrunnlaget kan det derfor ikke utelukkes at de etablerte effektene helt eller delvis skyldes konfunderende faktorer.

For å kunne kontrollere tredjevariabler og fastslå årsak-virkning-forhold er eksperimentelle studiedesigner påkrevd. Selv om eksperimentell manipulering av mobbing innebærer etiske utfordringer, viser forskning på sosial ekskludering at eksperimentelle studier er mulig (33).

\section{Konklusjon}

I teoretiske modeller vektlegges mobbing som en sentral risikofaktor for senere helseplager $(34,35)$. Disse modellene støttes av denne litteraturgjennomgangen ved at mobbing relateres til både somatiske og psykiske helseplager over tid. Signifikante sammenhenger i studier med både korte og lange tidsintervaller indikerer at mobbing er forbundet med økte helseplager uavhengig av tidsperspektiv.

Samlet sett indikerer gjennomgangen at eksponering for mobbing kan resultere i ulike vedvarende helseplager. Samtidig synes psykiske plager å være relatert til senere eksponering for mobbing. På grunn av begrensninger med prospektive spørreskjemastudier gir det eksisterende kunnskapsgrunnlaget ikke grunnlag for å konkludere om entydige årsakvirkning-forhold mellom mobbing og helseplager.

\section{Morten Birkeland Nielsen (f. 1977)}

er professor og har en ph.d.grad i arbeidsog organisasjonspsykologi.

Forfatter har fylt ut ICMJE-skjemaet og oppgir ingen interessekonflikter.

\section{Nils Magerøy (f. 1954)}

er lege, tidligere spesialist i allmennmedisin og har en ph.d.-grad i arbeidsmedisin. Han er enhetsleder ved Jobbfast.

Forfatter har fylt ut ICMJE-skjemaet og oppgir ingen interessekonflikter.

\section{Johannes Gjerstad (f. 1969)}

er dr.scient. og seniorforsker og professor II. Forfatter har fylt ut ICMJE-skjemaet og oppgir ingen interessekonflikter.

\section{Ståle Einarsen (f. 1963)}

er dr.psychol. og professor i arbeids og organisasjonspsykologi og forskningsleder for Forskningsgruppen for arbeidsmiljø, ledelse og konflikt (FALK)

Forfatter har fylt ut ICMJE-skjemaet og oppgir følgende interessekonflikter: Han har mottatt honorar for Arbeidsmiljøspesialistenes kurs i faktaundersøkelse.

\section{Litteratur}

1. Einarsen S, Hoel H, Zapf D et al. The concept of bullying and harassment at work: the European tradition. I: Einarsen S, Hoel H, Zapf D et al, red. Bullying and harassment in the workplace. Developments in theory, research, and practice. 2. utg. Boca Raton, FL: CRC Press, 2011: 3-40.

2. Einarsen $\mathrm{S}$, Pedersen $\mathrm{H}$. Håndtering av konflikter og trakassering i arbeidslivet. Oslo: Gyldendal Akademisk, 2007.

3. Nielsen MB, Einarsen S. Outcomes of workplace bullying: a meta-analytic review. Work Stress 2012; 26: 309-32

4. Nielsen MB, Skogstad A, Matthiesen SB et al. Prevalence of workplace bullying in Norway: comparisons across time and estimation methods. Eur J Work Organ Psychol 2009; 18: 81-101.

5. Brousse G, Fontana L, Ouchchane L et al. Psychopathological features of a patient population of targets of workplace bullying. Occup Med (Lond) 2008: 58: $122-8$

6. Eriksen W, Tambs K, Knardahl S. Work factors and psychological distress in nurses' aides: a prospective cohort study. BMC Public Health 2006; 6: 290.

7. Figueiredo-Ferraz H, Gil-Monte PR, Grau-Alberola E et al. Influence of some psychosocial factors on mobbing and its consequences among employees working with people with intellectual disabilities. J Appl Res Intellect Disabil 2012; 25: 455-63.

8. Finne LB, Knardahl S, Lau B. Workplace bullying and mental distress - a prospective study of Nor wegian employees. Scand J Work Environ Health 2011: 37: 276-87.

9. Hansen $\AA$ M, Hogh A, Garde AH et al. Workplace bullying and sleep difficulties: a 2-year follow-up study. Int Arch Occup Environ Health 2014; 87. 285-94.

10. Hoobler JM, Rospenda KM, Lemmon $G$ et al. A within-subject longitudinal study of the effects of positive job experiences and generalized workplace harassment on well-being. J Occup Health Psychol 2010; 15: 434-51.

11. Høgh A, Henriksson ME, Burr H. A 5-year followup study of aggression at work and psychological health. Int J Behav Med 2005; 12: 256-65.

12. Høgh A, Hoel H, Carneiro IG. Bullying and employee turnover among healthcare workers: a three-wave prospective study. J Nurs Manag 2011; 19: 742-51.

13. Johannessen HA, Tynes T, Sterud T. Effects of occupational role conflict and emotional demands on subsequent psychological distress: a 3-year follow-up study of the general working population in Norway. J Occup Environ Med 2013; 55: 605-13.

14. Kivimäki M, Virtanen M, Vartia M et al. Workplace bullying and the risk of cardiovascular disease and depression. Occup Environ Med 2003; 60: 779-83.

15. Kivimäki M, Leino-Arjas $P$, Virtanen $M$ et al. Work stress and incidence of newly diagnosed fibromyalgia: prospective cohort study. J Psychosom Res 2004: 57: 417-22 
16. Kääriä S, Laaksonen M, Rahkonen 0 et al. Risk factors of chronic neck pain: a prospective study among middle-aged employees. Eur J Pain 2012; 16: $911-20$

17. Lahelma E, Lallukka T, Laaksonen M et al. Workplace bullying and common mental disorders: a follow-up study. J Epidemiol Community Health 2012; 66: e3.

18. Lallukka T, Rahkonen O, Lahelma E. Workplace bullying and subsequent sleep problems-the Helsinki Health Study. Scand J Work Environ Health 2011: 37: 204-12

19. Lallukka T, Haukka J, Partonen T et al. Workplace bullying and subsequent psychotropic medication: a cohort study with register linkages. BMJ Open 2012: 2: e001660.

20. Nielsen MB, Hetland J, Matthiesen SB et al. Longitudinal relationships between workplace bullying and psychological distress. Scand J Work Environ Health 2012; 38: 38-46.

21. Nielsen MB, Tvedt SD, Matthiesen SB. Prevalence and occupational predictors of psychological distress in the offshore petroleum industry: a prospective study. Int Arch Occup Environ Health 2013; 86: 875-85.

22. Reknes I, Pallesen S, Magerøy N et al. Exposure to bullying behaviors as a predictor of mental health problems among Norwegian nurses: results from the prospective SUSSH-survey. Int J Nurs Stud 2014; 51: 479-87.

23. Rugulies R, Madsen IEH, Hjarsbech PU et al. Bullying at work and onset of a major depressive episode among Danish female eldercare workers. Scand J Work Environ Health 2012; 38: 218-27.

24. Stoetzer U, Ahlberg G, Johansson $G$ et al. Problematic interpersonal relationships at work and depression: a Swedish prospective cohort study. J Occup Health 2009; 51: 144-51.

25. Tepper BJ. Consequences of abusive supervision. Acad Manage J 2000; 43: 178-90.

26. Nielsen MB, Matthiesen SB, Einarsen S. The impact of methodological moderators on prevalence rates of workplace bullying. A meta-analysis. J Occup Organ Psychol 2010; 83: 955-79.

27. Ilies R, Hauserman N, Schwochau S et al. Reported incidence rates of work-related sexual harassment in the United States: Using meta-analysis to explain reported rate disparities. Person Psychol 2003; 56: 607-31.

28. Borenstein M, Hedges LV, Higgins JPT et al. Introduction to meta-analysis. Chichester: Wiley, 2009 29. Nielsen MB, Matthiesen SB, Einarsen S. Sense of coherence as a protective mechanism among targets of workplace bullying. J Occup Health Psychol 2008; 13: 128-36.

30. Vie TL, Glas $\varnothing$ L, Einarsen S. Health outcomes and self-labeling as a victim of workplace bullying J Psychosom Res 2011; 70: 37-43.

31. Cropanzano R, Stein JH, Nadisic T. Social Justice and the Experience of Emotion. New York: Routledge, 2010.

32. Haug TT, Mykletun A, Dahl AA. The association between anxiety, depression, and somatic symptoms in a large population: the HUNT-II study. Psychosom Med 2004; 66: 845-51.

33. Eisenberger NI, Lieberman MD, Williams KD. Does rejection hurt? An FMRI study of social exclusion. Science 2003; 302: 290-2

34. Bowling NA, Beehr TA. Workplace harassment from the victim's perspective: a theoretical model and meta-analysis. J Appl Psychol 2006; 91 : 998-1012.

35. Zapf D, Einarsen S. Mobbing at work: Escalated conflicts in organizations. I: Fox S, Spector PE, red. Counterproductive behavior Investigations of actors and targets. Washington D.C.: American Psychological Association, 2005.

Mottatt 2.7. 2013, første revisjon innsendt 23.9. 2013, godkjent 9.4. 2014. Redaktør: Sigurd Høye. 